\title{
PENGARUH MODEL PEMBELAJARAN INSIDE OUTSIDE CIRCLE BERBANTUAN COMIC CARD TERHADAP KOMPOTENSI PENGETAHUAN IPS KELAS V
}

\author{
Pt. Indah Sintya Devi' ${ }^{1}$, Md. Putra ${ }^{2}$, DB. Kt. Ngr. Semara Putra ${ }^{3}$ \\ ${ }^{1} J u r u s a n$ Pendidikan Dasar, Universitas Pendidikan Ganesha, Singaraja, Indonesia \\ 2Jurusan Pendidikan Dasar, Universitas Pendidikan Ganesha, Singaraja, Indonesia \\ ${ }^{3}$ Jurusan Pendidikan Dasar, Universitas Pendidikan Ganesha, Singaraja, Indonesia \\ e-mail:indah.sintya.devi@undiksha.ac.id ${ }^{1}$, madeputra@undiksha.ac.id ${ }^{2}$, semara.putra@undiksha.ac.id ${ }^{3}$
}

\begin{abstract}
Abstrak
Masalah dalam penelitian ini yaitu kurangnya variasi penggunaan model dan media dalam proses pembelajaran, sehingga mempengaruhi kompotensi pengetahuan ips siswa. Penelitian ini bertujuan untuk mengetahui pengaruh yang signifikan model pembelajaran inside outside circle berbantuan comic card terhadap kompetensi pengetahuan IPS siswa kelas V SD Gugus VIII Kecamatan Abiansemal Badung Tahun ajaran 2018/2019. Jenis penelitian yang dilakukan dalam penelitian ini adalah penelitian quasi eksperimen dengan rancangan Non-Equivalent Post-test Only Control Group Design. Populasi penelitian ini 9 kelas/kelompok siswa kelas V SD Gugus VIII Kecamatan Abiansemal Badung Tahun Ajaran 2018/2019 sebanyak 295 siswa. Penelitian ini menggunakan 2 kelompok yang terdiri dari kelompok eksperimen dan kelompok kontrol. Kedua kelompok ini dipilih dengan teknik random sampling. Metode pengumpulan data menggunakan metode tes dengan instrument berupa tes objektif pilihan ganda biasa. Data yang diperoleh dianalisis menggunakan uji-t dengan rumus polled varians. Berdasarkan hasil analisis dengan uji $\mathrm{t}$, diperoleh harga $t_{\text {hitung }}=4,21$, pada taraf signifikan 5\% dan $\mathrm{dk}=66$ diperoleh tabel 2,00 maka Ho ditolak. Ini berarti terdapat perbedaan yang signifikan kompotensi pengetahuan IPS antara kelompok eksperimen dan kelompok kontrol. Perbandingan hasil perhitungan rata-rata nilai post test kompetensi pengetahuan IPS kelompok eksperimen yaitu 82,09 lebih besar dari rata-rata kompotensi pengetahuan IPS kelompok kontrol yaitu 74,55. Dengan demikian dapat disimpulkan bahwa model pembelajaran inside outside circle berbantuan comic card memiliki pengaruh yang signifikan terhadap kompetensi pengetahuan IPS siswa kelas V SD Gugus VIII Kecamatan Abiansemal Badung Tahun Ajaran $2018 / 2019$.
\end{abstract}

Keywords:

Inside outside circle, comic card, kompotensi pengetahuan IPS

\section{Pendahuluan}

Pendidikan merupakan suatu hal yang perlu diperoleh setiap manusia, sebab pendidikan mendorong manusia untuk menjadi seseorang yang lebih baik dan meningkatkan pengetahuan serta keterampilan yang dimilikinya. Menurut Saidah (2016), Pendidikan diartikan sebagai proses perubahan sikap dan tata laku seseorang atau kelompok orang dalam usaha mendewasakan manusia melalui upaya pengajaran dan pelatihan. Keberhasilan pendidikan dipengaruhi oleh perubahan dan pembaruan segala kompenen pendidikan. Salah satunya adalah perubahan Kurikulum. 
Kurikulum adalah seperangkat rencana dan pengaturan mengenai tujuan, isi, dan bahan pelajaran serta cara yang digunakan sebagai pedoman penyelenggaraan kegiatan pembelajaran untuk mencapai tujuan pendidikan tertentu. Di Indonesia kurikulum telah mengalami beberapa kali perbaikan dan penyempurnaan. Pada pertengahan tahun 2013 tahun ajaran 2013/2014 kurikulum 2013 diimplementasikan secara terbatas pada sekolah perintis.

Kurikulum 2013 (K-13) adalah kurikulum yang berlaku saat ini dalam sistem pendidikan di Indonesia yang merupakan penyempurnaan dari kurikulum tingkat satuan pendidikan (KTSP). Tujuan kurikulum 2013 yaitu untuk mempersiapkan manusia Indonesia agar memiliki kemampuan hidup sebagai pribadi dan warga negara yang beriman, produktif, kreatif, inovatif, dan afektif serta mampu berkontribusi pada kehidupan bermasyarakat, berbangsa, bernegara, dan peradaban dunia. Pada kurikulum 2013 yang baru, guru dituntut untuk menerapkan teori yang terdapat didalam pembelajaran, guru tidak hanya sekedar memberikan teori saja, namun mampu mempraktekannya. Didalam kurikulum 2013 terdapat jenjang teori yang meliputi Mengingat, Memahami, menerapkan, menganalisis, dan mencipta (Kurniasih \& Sani, 2016).

Pelaksanaan kurikulum 2013 dilakukan melalui pembelajaran dengan pendekatan saintifik dengan tematik-terpadu dari kelas I sampai kelas VI. Dimana pendekatan saintifik dengan tematik terpadu ini mengaitkan beberapa mata pelajaran. Tujuan pemaduan beberapa mata pelajaran tersebut didalam kegiatan pembelajaran adalah agar para siswa saat belajar tidak menyadari sedang mempelajari mata pelajaran tertentu, sehingga siswa dapat memahami suatu konsep dan mampu menerapkannya ke kegiatan pembelajaran.

Kegiatan pembelajaran adalah inti dari kegiatan dalam pendidikan. Segala sesuatu yang telah direncanakan akan dilaksanakan dalam proses pembelajaran. Dalam kegiatan pembelajaran siswa diarahkan untuk mengembangkan potensi yang dimiliki menjadi kompetensi yang diharapkan. Tidak terlepas dari itu, ada beberapa komponen yang terlibat dalam proses pembelajaran yaitu, anak didik, guru, lingkungan belajar, materi pelajaran, pendekatan dan metode, media serta evaluasi pembelajaran. Komponen-kompenen yang ada di sekolah perlu bekerjasama secara ideal, agar tercapainya tujuan dalam mata pelajaran.

Berdasarkan informasi pada hari Sabtu, 24 November 2019 yang diperoleh dari Ketua Gugus, Kepala Sekolah dan seluruh Guru kelas V di SD Gugus VIII Kecamatan Abiansemal Badung Tahun Ajaran 2018/2019 dalam pelaksanaan pembelajaran tematik, khususnya pada muatan mata pelajaran IPS ada beberapa permasalahan yang muncul yaitu, terletak pada pemahaman siswa yang salah, yang beranggapan bahwa pelajaran IPS adalah pelajaran yang cenderung pada hapalan dan membosankan, sehingga minat siswa untuk mempelajari IPS kurang. Saat proses pembelajaran siswa kurang mampu dalam mengaitkan pengetahuan yang dimiliki dengan pengetahuan baru yang dipelajarinya dan kurangnya kemampuan mengomunikasikan. Serta kurang bervariasinya penggunaan model pembelajaran dan media pembelajaran, sehingga berpengaruh pada kompetensi pengetahuan IPS yang dimiliki siswa. kompetensi pengetahuan IPS adalah sesuatu perubahan perilaku siswa yang melalui proses belajar berupa mengingat, memahami, mengaplikasikan, menganalisis, dan mengevaluasi yang menunjukan kemampuan siswa terhadap pembelajaran IPS dari segi pengetahuan.

Mata pelajaran IPS disusun secara sistematis, komprehensif, dan terpadu dalam proses pembelajaran menuju kedewasaan dan keberhasilan dalam kehidupan di masyarakat. Dengan pendekatan tersebut diharapkan peserta didik akan memperoleh pemahaman yang lebih luas dan mendalam pada bidang ilmu yang berkaitan. (Badan Standar Nasional Pendidikan tahun 2006). Yusuf (2017:263) "Kompetensi merupakan perpaduan skill, tingkah laku dan pengetahuan serta nilai-nilai dasar yang dapat didemonstrasikan atau direfleksikan dalam kebiasaan dan kemampuan berpikir dan bertindak siswa yang dicapai melalui kegiatan mengajar yang bermakna dan penuh arti". Sedangkan menurut Kosasih (2016:14) "Kompetensi merupakan sesuatu yang kompleks, yang didalamnya mengandung banyak aspek (ranah). Bloom, dkk (1956) membagi kompetensi tersebut kedalam beberapa ranah, yakni (1) kompetensi kognitif, (2) kompetensi afektif, dan (3) kompoteni psikomotor".Jadi, dapat disimpulkan bahwa kompetensi merupakan gabungan dari beberapa aspek/ranah diantaranya, pengetahuan, keterampilan, sikap serta nilai-nilai dasar yang menjadi 
suatu acuan yang akan dicapai dalam kegiatan mengajar sehingga tercapainya kegiatan mengajar yang bermakna.

Menurut kosasih (2016:13), "pembelajaran yang berbasis kompetensi mengutamakan penciptaan dan peningkatan serangkaian kemampuan peserta didikserangkaian kemampuan peserta didik". Dalam kurikulum 2013, pengembangan aspek kompetensi dalam kurikulum 2013 ada 3 yaitu Sikap, pengetahuan, dan keterampilan. Kosasib (2016:16). Dari keempat kompetensi yang telah dipaparkan, Kompetensi pengetahuan adalah salah satu kompetensi yang dapat mengukur kemampuan siswa dalam memahami dan menguasai isi materi suatu pelajaran dengan jelas. Dimensi pengetahuan (dimensi proses kognitif) faktual dan konseptual terdiri dari mengingat, memahami, mengaplikasikan, dan menganalisis.

Kompetensi ranah kognitif berdasarkan taksonomi Bloom yang telah disempurnakan oleh Lorin Anderson Krathwohl meliputi mengingat, memahami, menerapkan, menganalisis, mengevaluasi, dan menciptakan. Revisi Krathwohl digunakan dalam merumuskan tujuan pembelajaran yang sering dikenal dengan istilah C-1 sampai C-6 (Kosasih, 2016:21). Uraian ranah kognitif tersebut sebagai berikut.

1. Mengingat, adalah kemampuan siswa untuk mengenali kembali sesuatu yang pernah diketahuinya dalam proses pembelajaran.

2. Memahami, adalah kemampuan siswa untuk mengerti suatu konsep, rumus, ataupun fakta untuk kemudian dinyatakan kembali dengan kalimat sendiri.

3. Menerapkan, mengaplikasikan adalah kemampuan melakukan atau mengembangkan sesuatu sebagai wujud dari pemahaman konsep tertentu.

4. Menganalisis, adalah kemampuan memisahkan suatu fakta atau konsep ke dalam beberapa komponen dan menghubungkannya satu sama lain ubtuk memperoleh pemahaman atas konsep secara utuh..

5. Mengevaluasi, adalah kemampuan di dalam menunjukkan kelebihan dan kelemahan sesuatu berdasarkan kriteria atau patokan tertentu.

6. Mencipta, adalah kemampuan yang mampu melakukan tidak sekedar tahu tetapi lebih dari itu, yaitu bisa melakukannya

Pembelajaran konvensional merupakan pembelajaran yang sering diterapkan dalam pembelajaran di kelas. Pada pelaksanaan pembelajaran konvensional Pemerintah menekankan menggunakan pendekatan saintifik. Adapun Langkah - langkah pembelajaran dengan pendekatan saintifik meliputi lima langkah yaitu :

1. Mengamati (Observing);

2. Menanya (Questioning);

3. Menalar (Associating);

4. Mencoba (Experimenting);

5. Mengomunikasikan

Pembelajaran dengan pendekatan saintifik adalah proses pembelajaran yang dirancang sedemikian rupa agar peserta didik secara aktif mengkontruksikan konsep (Daryanto,2014:51). Pendekatan saintifik disini dimaksud untuk memberikan pemahaman kepada peserta didik dalam mengenal, memahami materi dengan menggunakan pendekatan ilmiah, serta diharapkan mendorong peserta didik dalam mencari tahu sendiri dari berbagai sumber yang berasal dari mana saja, kapan saja dan tidak bergantung pada informasi dari guru saja.

Kompetensi pengetahuan dapat diperoleh dari kegiatan pembelajaran. Penelitian ini berfokus pada mata pelajaran IPS. Susanto (2014:6)“ Ilmu Pengetahuan Sosial (IPS) merupakan integrasi dari berbagai bidang ilmu-ilmu sosial dan humaniora, yaitu sosiologi, sejarah, geografi, ekonomi, politik, hukum, dan budaya". menurut Daryanto (2014:55), "Pendekatan saintifik diyakini sebagai titian emas bagi perkembangan dan pengembangan sikap, keterampilan, dan pengetahuan peserta didik". 
Berdasarkan kedua pendapat tersebut, dapat disimpulkan bahwa pendekatan saintifik adalah pendekatan yang secara aktif melibatkan siswa dalam mengkontruksi suatu konsep melalui kegiatan mengamati, menanya, mengumpulkan informasi, mencoba dan mengimunikasikan.

1. Tujuan pembelajaran dengan pendekatan saintifik

Tujuan pembelajaran dengan pendekatan saintifik didasarkan pada keunggulan pendekatan tersebut. Menurut Daryanto (2014), beberapa tujuan pembelajaran dengan pendekatan saintifik adalah (1)untuk meningkatkan kemampuan intelek, khususnya kemampuan berpikir tingkat tinggi siswa,(2)untuk membentuk kemampuan siswa dalam menyelesaikan suatu masalah secara sistematik,(3)terciptanya kondisi pembelajaran dimana siswa merasa bahwa belajar itu merupakan suatu kebutuhan,(4)diperolehnya hasil belajar yang tinggi,(5)untuk melatih siswa didalam mengomunikasikan ide-ide khususnya dalam menulis artikel ilmiah,(6)untuk mengembangkan karakter siswa.

IPS adalah suatu Ilmu Pengetahuan atau program pendidikan yang integrasi dari konsepkonsep ilmu sosial dan humaniora untuk mencapai tujuan pendidikan dan membentuk warga Negara atau masyarakat dengan kepribadian baik dan memiliki kompetensi sosial. Terdapat tiga kajian utama yang berkenaan dengan dimensi tujuan pembelajaran IPS di SD. Menurut Susanto (2014:13) "kajian utama yang berkenaan dengan dimensi tujuan pembelajaran IPS di SD ada tiga bagian yaitu, (1) pengembangan kemampuan berpikir siswa, (2) pengembangan nilai dan etika, (3) pengembangan tanggung jawab dan partisipasi sosial".

Kompetensi pengetahuan dapat diperoleh dari kegiatan pembelajaran. Penelitian ini berfokus pada mata pelajaran IPS. Susanto (2014:6)“ Ilmu Pengetahuan Sosial (IPS) merupakan integrasi dari berbagai bidang ilmu-ilmu sosial dan humaniora, yaitu sosiologi, sejarah, geografi, ekonomi, politik, hukum, dan budaya".

IPS adalah suatu Ilmu Pengetahuan atau program pendidikan yang integrasi dari konsepkonsep ilmu sosial dan humaniora untuk mencapai tujuan pendidikan dan membentuk warga Negara atau masyarakat dengan kepribadian baik dan memiliki kompetensi sosial. Terdapat tiga kajian utama yang berkenaan dengan dimensi tujuan pembelajaran IPS di SD. Menurut Susanto (2014:13) "kajian utama yang berkenaan dengan dimensi tujuan pembelajaran IPS di SD ada tiga bagian yaitu, (1) pengembangan kemampuan berpikir siswa, (2) pengembangan nilai dan etika, (3) pengembangan tanggung jawab dan partisipasi sosial".

(1) Pengembangan kemampuan berpikir siswa

Pengembangan kemampuan berpikir siswa adalah siswa diharapkan mampu mengembangkan kemampuannya dalam berpikir mengenai ilmu-ilmu sosial dan masalah-masalah kemasyarakatan. Yang terpenting dalam pengembangan kemampuan berpikir dalam bidang studi pendidikan IPS ini yaitu menumbuhkan atau membangkitkan cara berpikir kreatif dan inovatif. Kreatif yang dimaksud disini adalah seseorang mampu melahirkan sesuatu yang baru, baik itu berupa produk, gagasan atau ide nyata yang lain dengan yang sudah ada sebelumnya. Secara konseptual produk dapat dinilai kreatif jika memenuhi dua kategori, (1)produk tersebut bersifat baru, unik, berguna, dan bernilai dari segi kebutuhan, (2) bersifat heuristic, menampilkan metode yang jarang ditampilkan oleh orang lain.

(2) Pengembangan nilai dan etika,

Pengembangan nilai dan etika, nilai tidak hanya sebatas harga atau sesuatu yang penting saja namun nilai telah menempati posisi paling penting dalam hidup manusia, dimana didalamnya terdapat berupa keadilan, kejujuran, kebebasan, kedamaian, dan persamaan. Maka nilai merupakan sesuatu yang abstrak yang terdapat di dalam diri manusia,yang bisa kita ketahui melalui pola tingkah laku yang terlihat pada kehidupan sehari-hari. Sedangkan etika adalah segala bentuk cara berpikir mengenai pandangan perilaku manusia baik atau buruknya, dari norma-norma dan nilai-nilai pertanggungjawaban.

(3) Pengembangan tanggung jawab dan partisipasi sosial.

Pengembangan tanggung jawab dan partisipasi sosial yakni dengan mengembangkan tujuan ips dalam membentuk warga Negara yang baik, yang berpatisipasi aktif dalam kehidupan bermasyarakat. Selain itu kegiatan pembelajaran juga mengikuti prinsip-prinsip yang telah ada. Selain prinsip-prinsip terdapat juga karakteristik mata pelajaran IPS di SD, 
antara lain: (1) ilmu pengetahuan sosial merupakan gabungan dari beberapa unsur, (2) standar kompetensi dan Kompetensi dasar IPS dikemas sedemikian rupa sehingga menjadi suatu topik (tema ) tertentu, (3) Standar kompetensi dan Kompetensi dasar IPS juga menyangkut mengenai masalah sosial, (4) Standar kompetensi dan Kompetensi dasar IPS dapat ,menyangkut peristiwa kehidupan masyarakat dengan prisnsip sebab-akibat, (5) Standar kompetensi dan Kompetensi dasar IPS menggunakan tiga dimensi dalam mengkaji kehidupan manusia secara keseluruhan.

Melalui pendidikan IPS disekolah siswa diharapkan memiliki pengetahuan tentang konsep dasar ilmu sosial dan lingkungan, serta memiliki kepekaan dan kesadaraan terhadap masalah sosial lingkungannya dan menjadi sosok warga Negara yang bertanggung jawab (Lasmawan, 2016). Maka dilaksanakan penelitian dengan menerapkan model pembelajaran Inside Outside Circle berbantuan Comic Card.

Model pembelajaran Inside Outside Circle adalah suatu model yang menyenangkan sehingga dapat menumbuhkan situasi dan kondisi yang kondusif dan aktif didalam proses pembelajaran. Huda (2013:247) menyatakan, "Inside Outside Circle dapat diterapkan untuk beberapa mata pelajaran, seperti IPS (Ilmu Pengetahuan Sosial), Agama, Matematika, dan Bahasa". Sedangkan Shoimin (2014:87) menyatakan, "Inside Outside Circle adalah model pembelajaran dengan sistem lingkaran kecil dan lingkaran besar yang diawali dengan pembentukan kelompok besar dalam kelas yang terdiri dari kelompok lingkaran dalam dan kelompok lingkaran luar". Selain itu model Inside Outside Circle ini memungkinkan siswa untuk saling berbagi informasi pada waktu yang bersamaan dan memiliki banyak kesempatan untuk mengolah informasi dan meningkatkan keaktifan siswa.

Model pembelajaran IOC ini dapat diterapakan di beberapa mata pelajaran seperti: ilmu pengetahuan sosial, matematika, agama, dan bahasa. Dalam model ini bahan pelajaran yang cocok digunakan yaitu bahan-bahan yang memerlukan pertukaran pikiran dan informasi maupun wawasan antar siswa. Pembelajaran IOC mengajak siswa bekerja berkolaborasi untuk mencapai sebuah tujuan bersama, dimana siswa akan mampu mengembangkan keterampilan dan berkomunikasi dengan orang lain (Andhika,2013:2).Model Pembelajaran Inside Outside Circle yang disingkat menjadi IOC adalah suatu model yang menyenangkan untuk digunakan dalam proses mengajar sehingga dapat menumbuhkan situasi yang kondusif dan aktif didalam proses pembelajaran. Menurut Aqib (2016:30) menyatakan bahwa, "Model pembelajaran ini diperkenalkan oleh Spencer Kagan".

"Model pembelajaran ini sangat dinamis ketika dipraktekkan dengan benar, karena model ini memberikan kesempatan yang luas kepada siswa untuk bisa saling bertukar informasi pada saat bersamaan" (Kurniasih dan Sani, 2017:92).

Agar model Inside Outside Circle lebih menarik dan mudah dipahami maka model ini dipadukan dengan menggunakan media Comic Card atau Kartu komik. Kartu adalah sesuatu objek yang terbuat dari kertas tebal atau plastik Model pembelajaran Inside Outside Circle dapat dibantu dengan menggunakan media pembelajaran. "Media pada umumnya digunakan dengan tujuan untuk membuat proses belajar menjadi lebih efektif dan efisien" (Benny, 2017:13). "Media adalah kegiatan yang dapat menciptakan suatu kondisi, sehingga memungkinkan peserta didik dapat memperoleh pengetahuan, dan sikap yang baru" ( Ngalimun, 2017:82).

Penggunaan media pembelajaran didalam proses mengajar dapat membuat aktivitas belajar menjadi lebih menarik dan menyenangkan sehingga mampu meningkatkan motivasi belajar siswa, selain itu dengan menggunakan media pembelajaran proses penyampaian informasi dapat berlangsung efektif dan efisien (Benny,2017). Komik adalah salah satu media yang dapat digunakan sebagai media pembelajaran. Menurut Fitriani, (2015:84) "komik sebagai media intruksional edukatif, komik mempunyai sifat yang sederhana, jelas mudah dan bersifat personal". Selanjutnya menurut Yaumi, (2018:123) "komik adalah suatu bentuk karya seni yang menggunakan gambar-gambar tidak bergerak yang disusun sedemikian rupa sehingga membentuk jalinan cerita". Menurut Ningtyas dan Wuryani (2017), Adapun manfaat menggunakan komik antara lain , memperjelas materi, menciptakan nilai rasa lebih dalam memahami materi, membangkitkan perasaan senang anak-anak karena komik dilengkapi gambar, dan memotivasi siswa untuk belajar.

Comic Card ini dicetak diatas selembar kertas karton atau kertas tebal dan dilengkapi dengan teks dan gambaran yang sifatnya sederhana, jelas, dan mudah dipahami oleh pembaca. Menurut Fitriani (2015) Selain media instruksional edukatif, komik juga memiliki unsur-unsur diantaranya 
1. Sederhana, langsung, dan aksi-aksi yang cepat dan menggambarkan peristiwa-peristiwa.

2. Berisi unsur humor dan menggunakan bahasa percakapan.

3. Adanya kekuatan, dan keampuhan.

4. Adanya kecenderungan manusiawi terhadap pemujaan pahlawan.

Jadi dapat disimpulkan Comic Card adalah sesuatu objek yang terbuat dari kertas tebal yang berisikan gambar-gambar sederhana yang memuat pesan yang mudah untuk dicerna dan dipahami. Dengan demikian penggunaan media pembelajaran Comic Card akan membantu didalam meningkatkan pemahaman siswa mangenai suatu materi pembelajaran yang berpengaruh terhadap kompetensi pengetahuan IPS.

Jadi dapat disimpulkan bahwa penggunaan model pembelajaran Inside Outsie Circle berbantuan media Comic Card dapat memberi kesempatan kepada siswa untuk belajar mengemukakan pendapat dan saling bertukarkan informasi sehingga akan terciptanya siswa yang mandiri dan pembelajaran yang aktif serta dapat diaplikasikan secara langsung dalam kehidupan sehari-hari sehingga dapat berpengaruh terhadap kompetensi pengetahuan IPS siswa.

Berdasarkan uraian tersebut, maka dilaksanakan penelitian yang berjudul "Pengaruh Model Pembelajaran Inside Outside Circle Berbantuan Media Comic Card Terhadap Kompetensi Pengetahuan IPS Siswa Kelas V SD Gugus VIII Kecamatan Abiansemal Badung Tahun Ajaran 2018/2019”.

\section{Metode}

Rancangan penelitian ini merupakan penelitian kuantitatif, yaitu menggunakan desain penelitian eksperimen semu (quasi eksperimen). Hal ini dikarenakan tidak semua variabel yang muncul dalam ekperimen dapat diatur dan dikontrol secara ketat. Bentuk desain eksperimen semu yang digunakan dalam penelitian ini adalah Non-equivalen Post test only control grup design, yang secara prosedural mengikuti pola yang ditunjukan oleh gambar dibawah ini.

\begin{tabular}{lll}
\hline Kelas & Perlakuan & Post-test \\
\hline Eksperimen & $\mathrm{X}_{1}$ & $\mathrm{O}_{1}$ \\
\hline Kontrol & $\mathrm{X}_{2}$ & $\mathrm{O}_{2}$ \\
\hline
\end{tabular}

Gambar 1 Rancangan Non-equivalent Post test only control grup design

(Sumber : Agung,2014:163)

\section{Keterangan :}

$\mathrm{X}_{1} \quad$ :Perlakuan dengan penerapan model pembelajaran Inside Outside Circle berbantuan Comic Card pada kelompok eksperimen.

$\mathrm{X}_{2} \quad$ :Dibelajarkan secara konvensional pada kelompok kontrol.

$\mathrm{O}_{1} \quad$ :Menyatakan pengamatan akhir (pos-test) pada kelompok eksperimen.

$\mathrm{O}_{2} \quad$ :Menyatakan pengamatan akhir (pos-test) pada kelompok kontrol.

Pada desain ini melibatkan dua kelompok kelas yaitu kelompok kelas eksperimen dan kelompok kelas kontrol. Kelompok eksperimen diberikan pembelajaran Inside Outside Circle berbantuan Comic Card, sedangkan untuk kelompok kontrol pembelajaran secara konvensional. Dalam penelitian ini penyetaraan menggunakan nilai ulangan harian IPS dan Teknik yang digunakan yaitu uji t.

Teknik pengambilan sampel yang digunakan pada penelitian ini dilakukan dengan teknik Random Sampling atau Sampel Acak Sederhana. Dimana pada saat pengambilan sampel yang di random adalah kelasnya, sehingga semua kelas mendapatkan peluang yang sama untuk menjadi sampel penelitian.

Penentuan sampel yang dipilih menjadi kelompok eksperimen dan kelompok kontrol dilakukan dengan cara pengundian. Cara ini dilakukan agar semua anggota populasi mempunyai kesempatan yang sama untuk dipilh menjadi sampel. Teknik undian ini menggunakan potongan kertas yang ditulisakan masing-masing nama anggota populasi kemudian digulung dimasukan ke dalam wadah. Kemudian kertas gulungan tersebut dikocok sehingga mendapatkan dua buah kertas. Nama yang tercantum dalam kedua kertas tersebutlah yang menjadi sampel penelitian. Setelah dilakukan undian 
diperoleh hasil dua kelompok yang terpilih sebagai sampel penelitian yaitu kelas V di SD No 1 Sibanggede dan kelas V di SD No. 4 Sibanggede.

Setelah itu, dilakukan uji prasyarat untuk memenuhi syarat melakukan uji kesataraan yaitu dengan menggunakan uji-t. Selanjutnya, setelah sampel setara, pengundian kedua dilakukan untuk memilih kelas eksperimen dan kelas kontrol.

Data yang dikumpulkan dalam penelitian ini adalah data kompetensi pengetahuan pada mata pelajaran IPS siswa kelas V SD Gugus VIII Kecamatan Abiansemal Badung Tahun Ajaran 2018/2019. Data kompetensi pengetahuan IPS ini dikumpulkan dengan menggunakan metode tes. Tes yang digunakan yaitu tes objektif dalam bentuk pilihan ganda biasa. Dalam penelitian ini menggunakan tes pilihan ganda biasa yang sudah tervalidasi.

Metode analisis data yang digunakan dalam penelitian ini yaitu statistic inferensial. analisis inferensial yang diunakan dalam penelitian ini adalah uji-t ( $t$-test). Untuk dapat menggunakan teknik analisis tersebut dibutuhkan data yang berdistribusi normal dan homogen. Maka, perlu dilakukan uji normalitas data dan uji homogenitas untuk memenuhi prasyarat yang dibutuhkan untuk menggunakan teknik analisis Uji-t ( $t$-test).

\section{Hasil dan Pembahasan}

\section{Hasil}

Deskripsi data hasil kompetesnsi peng-etahuan IPA siswa yang dipaparkan me-liputi nilai rerata, varians, dan standar deviasi.

Nilai rerata kompetensi pengetahuan IPS siswa kelompok eksperimen yang menggunakan model pembelajaran inside outside circle, yaitu $\bar{X}=82,09$ dengan varians 59,79 dan standar deviasi $(s=7,73)$, sedangkan nilai mean atau rerata kompetensi pengetahuan IPA siswa yang mengikuti pembelajaran konvensional, yaitu $\bar{X}=74,55$ dengan varians 48,76 dan standar deviasi $(s=6,98)$. Perhitungan analisis data hasil penelitian yang diperoleh menunjukkan bahwa kompetensi pengetahuan IPS kelompok eksperimen yakni siswa yang mengikuti pembelajaran menggunakan model pembelajaran inside outside circle berbasis Eksperimen memiliki nilai mean lebih tinggi daripada kelompok kontrol yakni siswa yang mengikuti pem-belajaran menggunakan pembelajaran konvensional yaitu $\bar{X}=$ $82,09>\bar{X}=74,55$.

Uji prasyarat dilakukan terlebih dahulu sebelum uji hipotesis menggunakan uji-t.Uji prasyarat tersebut meliputi uji normalitas dan uji homogenitas varians.

Berdasarkan hasil uji prasyarat yang terdiri dari uji normalitas dan uji homogenitas varians, disimpulkan bahwa data kedua kelompok sampel ialah berdistribusi normal dan memiliki varians yang homogen.Dengan demikian, uji hipotesis menggunakan uji-t dapat dilakukan.

Hipotesis yang diuji dalam penelitian ini adalah tidak terdapat pengaruh yang signifikan model pembelajaran inside outside circle berbantuan comic card terhadap komtentensi pengetahuan IPS siswa kelas V SD Gugus VIII Kecamatan Abiansemal Badung Tahun Ajaran 2018/2019. Hasil uji prasyarat yang meliputi uji normalitas dan homogenitas varians yang dilakukan dalam penelitian ini diperoleh kedua kelompok sampel berdistribusi normal dan memiliki varians yang homogen. Analisis statistik yang digunakan untuk menguji hipotesis penelitian ini ad-alah uji-t dengan polled varians. Ber-dasarkan hasil perhitungan uji-t, diperoleh thitung $=4,21$ dan untuk taraf signifikansi $5 \%$ dengan $\mathrm{dk}=(35+33-2)=66$ diperoleh $t_{\text {tabel }}=2,00$. Dengan demikian, nilai $t_{\text {hitung }}>t_{\text {tabelyakni }} 4,21>2,00$ sehingga $H_{o}$ ditolak.

Berdasarkan hasil analisis uji-t dari nilai posttest kompetensi pengetahuan IPS siswa diperoleh hasil sebagai berikut.

Tabel 1 Hail Analisis Uji-t Data Posttes 


\begin{tabular}{|c|c|c|c|c|c|c|c|c|}
\hline No & Sampel & $\begin{array}{c}\text { Rata-rata } \\
(\mathrm{x})\end{array}$ & Varians s2 & $\mathbf{d k}$ & $\mathbf{n}$ & $t_{\text {hitung }}$ & $t_{\text {tabel }}$ & Kesimpulan \\
\hline 1 & $\begin{array}{l}\text { Kelompok } \\
\text { Eksperimen }\end{array}$ & 82,09 & 59,79 & \multirow[t]{2}{*}{66} & 35 & \multirow[t]{2}{*}{4,21} & \multirow[t]{2}{*}{2,00} & \multirow[t]{2}{*}{ Ho ditolak } \\
\hline 2 & Kelompok Kontrol & 74,55 & 48,76 & & 33 & & & \\
\hline
\end{tabular}

Ber dasarkan hasil perhitungan uji-t, diperoleh $\mathrm{t}_{\text {hitung }}=4,21$ dengan taraf signifikansi $5 \%$ dengan dk $=$ $((35+33)-2)=66$ diperoleh $t_{\text {tabel }}=2,00$. Dengan demikian, nilai $t_{\text {hitung }}>t_{\text {tabel }}$ yakni $4,21>2,00$ sehingga Ho ditolak. Hal ini menunjukkan bahwa terdapat perbedaan yang signifikasi kompetensi pengetahuan IPS anatara kelompok siswa yang dibelajarkan menggunakan model pembelajaran Inside Outside Circle berbantuan Comic Card dengan kelompok siswa yang tidak dibelajarkan dengan model pembelajaran Inside Outside Circle berbantuan Comic Card siswa kelas V SD Gugus VIII Kecamatan Abiansemal Badung Tahun Ajaran 2018/2019.

\section{Pembahasan}

Berdasarkan hasil analisis data penelitian pada kedua kelas yaitu diperoleh bahwa rata-rata kompetensi pengetahuan IPS pada kelas eksperimen adalah $\bar{X}=82,09$ dan kelas kontrol adalah $\bar{X}=74,55$. Selanjutnya dilakukan uji hipotesis dan diperoleh $t_{\text {hitnung }}=4,21$ sedangkan pada taraf signifikansi $5 \%$ dan $\mathrm{dk}=66$ diperoleh nilai $t_{\text {tabel }}=2,00$ sehingga $t_{\text {hitnung }}=4,21>t_{\text {tabel }}=2,00$. Dengan demikian, hipotesis nol $\left(\mathrm{H}_{\mathrm{o}}\right)$ ditolak. Hal ini berarti terdapat pengaruh yang signifikan model pembelajaran Inside Outside Circle berbantuan Comic Card terhadap kompotensi pengetahuan IPS siswa kelas V SD Gugus VIII Kecamatan Abiansemal Baudng Tahun Ajaran 2018/2019.

Berdasarkan hasil temuan tersebut, setelah diberikan perlakuan berupa pembelajaran dengan menggunakan model Inside Outside Circle berbantuan Comic Card dan mengikuti pembelajaran menggunakan model pembelajaran konvensional diperoleh kompotensi pengetahuan IPS yang berbeda. Hal ini dapat dilihat juga dari nilai rata-rata siswa yang mengikuti pembelajaran menggunakan model Inside Outside Circle berbantuan Comic Card lebih tinggi dibandingkan dengan rata-rata siswa yang mengikuti pembelajaran konvensional. Perbedaan kompotensi pengetahuan IPS dengan perolehan nilai rata-rata yang lebih tinggi pada kelompok eksperimen dibandingkan kelompok kontrol disebabkan oleh perlakuan berupa model pembelajaran Inside Outside Circle berbantuan Comic Card dalam kompotensi pengetahuan siswa pada mata pelajaran IPS yang diberikan pada kelompok eksperimen.

Kompetensi pengetahuan siswa pada kelas eksperimen lebih tinggi apabila dibandingkan dengan kompetensi pengetahuan siswa pada kelas kontrol. Hal ini disebabkan oleh model pembelajaran Inside Outside Circle berbantuan Comic Card dapat menarik minat siswa dan memotivasi siswa belajar lebih aktif. Selain itu, Pembelajaran Inside Outside Circle merupakan pembelajaran dimana siswa diberikan kesempatan untuk mengemukakan informasi yang didapat dan saling berbagi informasi dengan teman yang lain. Dalam penerapan model pembelajaran IOC didukung oleh penggunaan media Comic Card dengan adanya media Comic Card dapat menarik minat siswa dan mempermudah siswa dalam memahami materi pelajaran yang akan dibelajarkan.

Model pembelajaran Inside Outside Circle adalah model yang sangat dinamis ketika dipraktekkan dengan benar. Model pembelajaran ini memiliki struktur yang jelas yang memungkinkan siswa untuk berbagi informasi secara aktif dengan pasangan yang berbeda dengan singkat dan teratur. Selain itu siswa bekerja dengan sesama siswa dalam suasana gotong royong ( Kurniasih \& Sani, 2017). Model pembelajaran Inside Outside Circle dapat dibantu dengan media yaitu Comic Card. Comic adalah salah satu media grafis yang menggunakan gambar tidak bergerak yang disusun sehingga memiliki sebuah alur cerita ( Yaumi, 2018). Dan Card yaitu sesuatu objek yang terbuat dari kertas tebal atau plastik. Model pembelajaran Inside Outside Circle berbantuan Comic Card adalah model pembelajaran yang mempunyai tiga Fase pembelajaran yang dimana hanya pada Fase kedualah yang dapat dibantu dengan penggunaan Comic Card yang sederhana dimana dengan menggunakan media ini siswa lebih mudah paham dan menarik minat siswa serta mampu membangkitkan peran aktif siswa dalam proses pembelajaran yang melatih kemandirian siswa dan berbicara menyampaikan informasi secara teratur 
Hasil temuan pada penelitian ini didukung dengan hasil penelitian (Virgawati,2017) yang berjudul "Pengaruh Model Pembelajaran Kooperatif Tipe Inside Outside Circle Terhadap Hasil Belajar IPS Siswa Kelas V" menyatakan bahwa terdapat perbedaan yang signifikan hasil belajar IPS siswa kelas V yang dibelajarkan dengan model pembelajaran kooperatif tipe inside outside circle dengan siswa kelas $\mathrm{V}$ yang dibelajarkan dengan model pembelajaran konvensional mata pelajaran IPS di Gugus III Kecamatan Mendoyo Kabupaten Jembrana tahun pelajaran 2016/2017. Selain itu penelitian yang dilakukan (Somarasih,2017) yang berjudul "Pengaruh Model Pembelajaran Kooperatif Tipe Inside Outside Circle (IOC) Berbasis Konsep Tri Kaya Parisudha terhadap Hasil Belajar IPA Siswa Kelas IV" yang menyatakan bahwa model pembelajaran kooperatif tipe Inside Outside Circle berbasis Tri Kaya Parisudha berpengaruh terhadap Hasil Belajar IPA Siswa kelas V dan penelitian yang dilakukan (Sumiantini,2014) yang berjudul "Pengaruh Model Pembelajaran Terpadu Tipe Connected Berbantuan Media Komik Terhadap Hasil Belajar IPA Kelas V” yang menyatakan bahwa penerapan model pembelajaran terpadu tipe connected berbantuan media komik berpengaruh terhadap hasil belajar IPA siswa kelas V Gugus X Kecamatan Buleleng tahun pelajaran 2013/2014 Berdasarkan pemaparan tersebut, dapat disimpulkan bahwa penerapan model pembelajaran IOC berbantuan Comic Card berpengaruh terhadap kompetensi pengetahuan IPS siswa kelas V SD di Gugus VII Kecamatan Abiansemal Badung Tahun Ajaran 2018/2019.

\section{Simpulan}

\section{Simpulan}

Jadi dapat disimpulkan bahwa model pembelajaran inside outside circle berbantuan comic card berpengaruh terhadap kompotensi pengetahuan ips siswa kelas v sd gugus viii Kecamatan abiansemal badung tahun ajaran 2018/2019. Hasil penelitian analisis data post test menunjukkan bahwa rata-rata kompetensi pengetahuan IPS kelas ekseperimen lebih tinggi daripada rata-rata kelas kontrol $(82,09>$ 74,55). Berdasarkan hasil analisis uji-t diperoleh sebesar 4,21 dan dengan $\mathrm{dk}=35+33-2=66$ pada taraf signifikansi 5\% adalah 2,00 karena $(4,21>2,00)$ maka H0 ditolak.

\section{Saran}

Berdasarkan hasil penelitian ini, maka saran yang dapat diajukan adalah sebagai berikut.

1. Kepada Guru

Berdasarkan temuan penelitian yang diperoleh, disarankan kepada guru agar lebih kreatif untuk memberikan fasilitas berupa sumber belajar dan kesempatan yang lebih besar bagi siswa pada pembelajaran dengan menggunakan model pembelajaran Inside Outside Circle berbantuan Comic Card sehingga tercipta pembelajaran bermakna dan menyenangkan bagi siswa.

2. Kepada Kepala Sekolah

Hasil penelitian ini dapat dijadikan pedoman bagi sekolah untuk menciptakan kondisi yang mampu memotivasi dan meningkatkan kualitas guru-guru dalam merancang pembelajaran yang inovatif dalam membelajarkan siswa sesuai dengan yang diharapkan dalam kurikulum 2013, sehingga dapat meningkatkan mutu dan kualitas sekolah menjadi lebih unggul dan inovatif.

3. Kepada Peneliti Lain

Dengan dilakukannya penelitian ini, peneliti lain dapat melakukan penelitian lebih lanjut mengenai model pembelajaran Inside Outside Circle berbantuan Comic Card pada tema serta pembelajaran yang lain dan dapat mengembangkan kreativitas siswa untuk memperoleh hasil yang lebih baik.

\section{Ucapan Terimakasi}

Sebagai rasa syukur melalui kesempatan ini saya sampaikan ucapan terima kasih kepada Universitas Pendidikan Ganesha yang telah memberikan konstribusi baik berupa arahan maupun acuan didalam penyusunan artikel ini, tidak mengurangi rasa hormat saya ucapkan terimakasih juga kepada kedua dosen pembimbing yang telah senantiasa membimbing dalam penyusunan artikel ini dari awal hingga akhir penyusunan, serta saya mengucapkan terimakasih kepada orang tua , keluarga, rekan-rekan mahasiswa dan teman dekat saya atas dukungan dana maupun moral yang diberikan selama penyusunan artikel dan skripsi hingga selesai. 


\section{Daftar Pustaka}

Agung, A.A.G. 2014. Metodologi Penelitian Pendidikan. Malang: Aditya Media Publishing.

Aqib, Zainal. 2017. Model-Model, Media, Dan Strategi Pembelajaran Kontekstual (Inovatif). Bandung: Penerbit Yrama Widya.

Badan Standar Nasional Pendidikan, 2006. Kurikulum Tingkat Satuan Pendidikan (KTSP). Jakarta: Departemen Pendidikan Nasiona

Benny, A. 2017. Media Dan Teknologi Dalam Pembelajaran. Jakarta: Kencana.

Fitriani, E L. 2015. " Penerapan Model Mind Map Berbantuan Media Komik Untuk Meningkatkan Kualitas Pembelajaran Pkn Pada Siswa Kelas IV SDN Kalibanteng Kidul 02 Semarang”. Ilmu Pendidikan. Universitas Negeri Semarang. Semarang.

Huda, Miftahul. 2013. Model-Model Pengajaran Dan Pembelajaran. Yogyakarta: Pustaka Pelajar. Kurniasih, Imas dan Sani Berlin. 2017. Ragam Pengembangan Model Pembelajaran. Kata Pena. Kurniasih, Imas dan Berlin, Sani. 2016. Revisi Kurikulum 2013 Implementasi Konsep Dan Penerapan. . Lasmawan, Wayan. 2016. Pendidikan Ips. Singaraja: Mediakom Indonesia Press Bali. Ngalimun. 2017. Strategi Pendidikan. Yogyakarta: Penerbit Parama Ilmu Ningtyas, dkk. (2017). "Penerapan Model Pembelajaran Kooperatif (Cooperative Learning) Tipe MakeA Match Berbantuan Media Komik Interaktif Untuk Meningkatkan Aktivitas Belajar dan Hasil Belajar IPS". Program Studi PGSD FKIP Universitas Kristen Satya Wacana. Volume 3, Nomor 1 (hlm 1-10).Tersedia pada https://media.neliti.com/media/publications/122330-IDnone.pdf(diakses tanggal 28 Januari 2019).

Saidah, H. 2016. Pengantar Pendidikan. Jakarta: PT Raja Grafindo Persada.

Shoimin, Aris. 2014. 68 Model Pembelajaran Inovatif Dalam Kurikulum 2013. Yogyakarta: Ar-Ruzz Media.

Somariasih, dkk. (2017). "Pengaruh Model Pembelajaraan Kooperatif Tipe Inside Outside Circle (IOC) Berbasis Konsep Tri Kaya Parisudha Terhadap Hasil Belajar IPA Siswa Kelas V". Jurusan Pendidikan Guru Sekolah Dasar FIP Undiksha. Volume 5, Nomor 2 (hlm 1-10). Tersedia pada http://ejournal.undiksha.ac.id/index.php/IJPGSD/article/view/10931 (diakses tanggal 3 Januari 2019)

Sugiyono. 2017. Statistika untuk Penelitian. Bandung:Alfabeta,CV.

Sugiyono. 2018. Statistika untuk Penelitian. Bandung:Alfabeta,CV.

Sumiantini, dkk. (2014). "Pengaruh Model Pembelajaran Terpadu Tipe Connected Berbantuan Media Komik Terhadap Hasil Belajar IPA Kelas V". Jurusan Pendidikan Guru Sekolah Dasar FIP Undiksha. Volume 2, Nomor 1 (hlm 1-10) Tersedia Pada https://ejournal.undiksha.ac.id/index.php/JJPGSD/article/view/3790(diakses tanggal 28 Januari 2019).

Susanto, Ahmad. 2014. Pengembangan Pembelajaran Ips Di Sekolah Dasar. Jakarta: Prenamedia Group. Yaumi. 2018. Media dan Teknologi Pembelajaran. Jakarta: Prenadamedia Group.

Yusuf, Muri. 2017. Asesmen dan Evaluasi Pendidikan. Jakarta: Kencana.

Virgawati, dkk. (2017). "Pengaruh Model Pembelajaran Kooperatif Tipe Inside Outside Circle Terhadap Hasil Belajar IPS Siswa Kelas V". Jurusan Pendidikan Guru Sekolah Dasar FIP Undiksha. Volume 5, Nomor 2 (hlm 1-10) Tersedia Pada https://ejournal.undiksha.ac.id/index.php/IJPGSD/article/view/10886(diakses tanggal 28 Januari 2019). 